\title{
SWOT ANALYSIS OF THE RURAL TOURISM AS A CHANNEL OF MARKETING FOR AGRICULTURAL PRODUCTS IN SERBIA
}

Biljana Chroneos Krasavac ${ }^{1}$, Katica Radosavljević ${ }^{2}$,Aleksandra Bradić-Martinovic ${ }^{3}$

*Corresponding authorE-mail: abmartinovic@ien.bg.ac.rs

A R T I C L E I N F O
Review Article
Received: 25 October 2018
Accepted: 16 November 2018
doi:10.5937/ekoPolj1804573K
UDC $005.33+338.48-44(1-$
22):658.8+338.432(497.11)

Keywords:

rural tourism, marketing channel, SWOT analysis, food production, Serbia

JEL: Q01, Q13, Z30

\section{A B S T R A C T}

In many countries, rural areas are undergoing significant socio-demographic and economic changes, and this trend is also present in Serbia. From the economic and demographic point of view, and this is particularly true for southern Serbia, the problem of depopulation, ageing and extinction of the village has arisen. The subject of this paper is rural tourism in Serbia, which is observed in the context of the new channel for marketing agricultural products of rural households and analyzed by SWOT methodology in order to capture all strengths, weaknesses, opportunities and possible threats. Results show that one of the highest priorities is the synthesis of agriculture and tourism in Serbia, which would be the basis for the development of diversification in rural communities. The development and advancement of the rural environment represent a sustainable and stable regional economic development.

(C) 2018 EA. All rights reserved.

\section{Introduction}

Current social and economic developments condition the migration of the population into urban environments. During the last century, massive urban migration was recorded for employment purposes, as a consequence of the development of the tertiary sector in developed countries and the secondary sector in developing countries. Also, modern agriculture is mechanized and requires an even smaller share of manual labour. As a consequence, today more than half of the population lives in cities, which has many advantages and disadvantages. From the economic and demographic point of view, and this is particularly true for southern Serbia, the problem of depopulation, ageing and

1 Biljana Chroneos Krasavac, PhD, Associate Professor, Faculty of Economics University of Belgrade, Kamenička 6,Republic of Serbia, Phone: +381 63379 074, e-mail: biljachronkra@ me.com, https://orcid.org/0000-0002-1486-4825.

2 Katica Radosavljević, PhD, Research Associate, Faculty of Economics University of Belgrade, Kamenička 6, Republic of Serbia, Phone: +381 638127 014, e-mail: katica@ ekof.bg.ac.rs, https://orcid.org/0000-0002-5609-8399.

3 Aleksandra Bradić-Martinović, $\mathrm{PhD}$, Senior Research Associate, Institute of Economic Sciences Belgrade, Zmaj Jovina 12, Republic of Serbia, Phone: +381 6412332 54, e-mail: abmartinovic@ien.bg.ac.rs, https://orcid.org/0000-0002-5930-9278. 
extinction of the village has arisen. On the other hand, the urban population is exposed to problems of urban life, noise, pollution and exposure to stress, which leads to the occurrence of mental disorders such as anxiety and depression. One way of alleviating these bad trends is the development and affirmation of rural tourism. Economically, rural tourism enables the development of rural households, and tourists from cities provide an excellent opportunity to escape stressful life and stay in an authentic rural environment. For the sustainable rural agriculture it is necessary to develop the technology of crops production with achieving economic profitability, social and economic equity and environmental and food security the conclusion are Radosavac \& Knežević (2017). Rural tourism can also be considered as an important component of the integral and sustainable development of the village, as it encourages local economic growth through the development of agricultural and non-agricultural activities, with the incentive for employment. Tourism development also provides opportunities for small agricultural producers to increase their revenues by selling surplus production to the local tourism sector and thus improve their standard. In turn, increasing the supply of local food products can have a positive impact on the tourism sector, as it builds an authentic tourist offer. Therefore, the establishment of links between the production of agricultural food and rural tourism can contribute to the economic development of the village, and in certain circumstances even confront the migrations of the population and capital.

Food industry occupies a high position in a competitive international tourism market, but it is not sufficiently developed in the field of academic studies. A particular problem is the imbalance of the research, as the research is dominated by considerations on the supply side, including links between food and culture, agriculture, image destinations and branding, development and marketing (Robinson \& Getz, 2014), while incomparably fewer papers are dealing with the topic demand and consumer preferences.

The subject of this paper is rural tourism in Serbia, which is observed in the context of the new channel for marketing agricultural products of rural households. The aim of the work is to use the SWOT methodology to analyze the strengths and weaknesses of rural tourism in the presented context, as well as analyze the opportunities and risks of the environment and point out the advantages and disadvantages of this concept, bearing in mind that the model of integral rural development, in addition to modern agriculture, encourages the development of complementary activities, in this case, the production and sale of agricultural products through rural tourism activities. We believe that the topic is very important and current, considering the socio-demographic situation of rural areas in the Republic of Serbia.

The work is divided into five parts. In the first part, rural tourism was generally presented as a channel of marketing of food products, while in the second part the analysis of the possibility of applying the model of the chain for the value of agro-food products in the function of rural tourism in Serbia was carried out. The third part is devoted to the analysis of general trends in tourism in Serbia. The fourth and key part of the paper presents the results of the SWOT analysis, while suggestions for the guidelines are presented in conclusion to improve the presented concept. 


\section{Rural tourism as a food marketing channel}

Nowadays, we are witnessing a change in the tourism paradigm, which refers to a radical shift in the values and beliefs of all stakeholders. Viewed from the business side, the financial result is no longer the only measure of success, but attention is increasingly focused on the sustainability principle while preserving the existing values. In this process, keywords are ecology, equilibrium, health, holistic approach. From the perspective of tourists, trips are increasingly aimed at authentic and unique experiences, while approaching the local style of life, unlike in the past when sightseeing, leisure and entertainment were the basis of a tourist offer (i.e. sightseeing, sun and beach). These changes lead to the insight that mass tourism is no longer the "best practice", which leads to service providers turning increasingly towards the individual, flexible and tailor-made tourism (TII, 2012).

Rural tourism is largely aligned with the new needs of tourists because through this form of tourism they are given the opportunity to experience natural beauty in the authentic accommodation of a particular region. On the other hand, according to Ružić \& Demonja (2017), rural tourism brings a number of local economic benefits, of which the most important is the growth of total income, employment, entrepreneurial activity and investments, as well as the stimulation of general economic growth and development, as well as the increase in living standards of local population. The development of rural tourism is also seen as a way of raising the economic resilience of rural areas (Akin, Shaw \& Spartz, 2015). In addition to these benefits, the development of rural tourism opens another channel of marketing of agro-food products. In this way, new business initiatives are being launched and mutually beneficial about existing agricultural production and tourism. In this way, agricultural products and traditional handicrafts are developed (product development, commercialization), unemployment is reduced, resulting in the revival of the extinct villages. Young people get new employment opportunities, which in the long run can result in stopping the trend of depopulation in the villages, as well as the activation of women, which today are in the vulnerable category of population, especially in the rural areas of central and southern Serbia. One of the central goals of rural tourism development is the mobilization of the agricultural sector in the development of agricultural products that can be offered in the rural tourism sector to the end consumer or other users in the value chain.

Henderson (2009) points out that the assortment of food has become an important tourist attraction and occupies one of the central places in the tourist experience. In many cases, it has taken on a prominent role in decision making and the satisfaction of tourists, tourism products and promotion strategies. Many destinations promote themselves as food centres and emphasize food products and experiences as an attraction for tourists. Special attention is paid to understanding the "specific requirements of different tourist markets". For example, Smith and Xiao (2008) developed a range of competitive advantages of foodstuffs (wines) and explained the visitors' experience, while (Sparks et al., 2005) found that food and wine are very important for the experience that tourists acquire. 
By developing rural tourism, local farmers are given the opportunity to sell their agricultural products to enterprises engaged in rural accommodation or catering, further developing the supply chain. For some tourists, especially from foreign countries, it would also be interesting to participate in the production of food or to cook traditional dishes. (Hüller et al., 2017).

Huller et al. (2017), based on the empirical research carried out in Kazbegi district (Georgia, US), and the Springer-Haize model (2007) offered a customized agri-food chain model in rural tourism.

Figure 1. The agri-food chain model

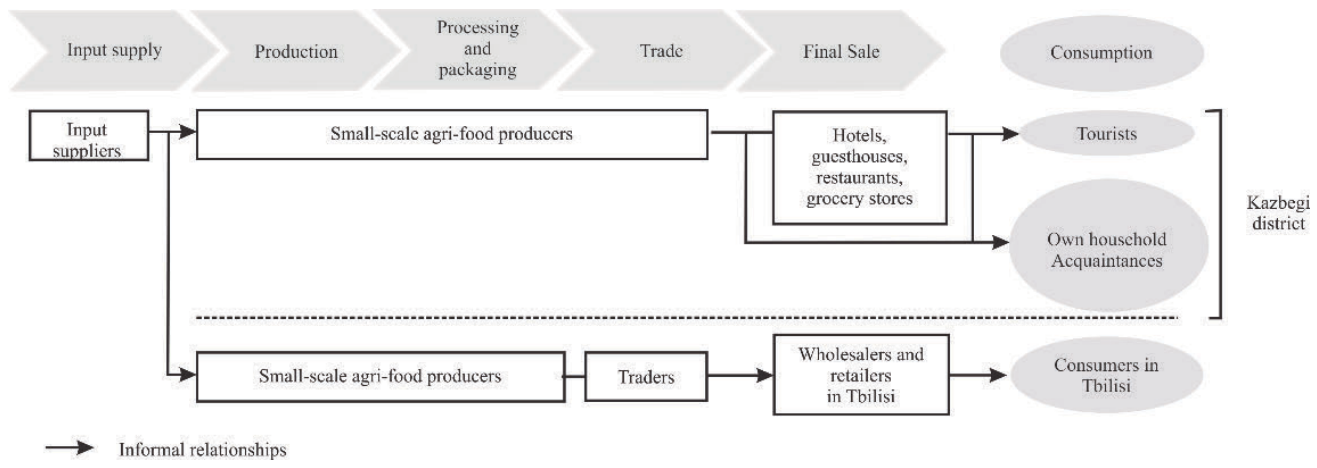

Source: Huller et al. (2017)

The chart includes the stages and participants in the value chain, from input suppliers, through small-scale agri-food producers, to distributors and users (hotels, guesthouses, restaurants, wholesalers and tourists through direct consumption). The main advantage of this model is that it highlights the fact that the number of intermediaries located between the food producers and the end intermediary is very small, and in some cases intermediaries are not involved (when the farmer organizes food sales in his household, within his tourist offer). Another important feature of this supply chain model is that a tourist, a guest at the farm's farmhouse, is fully informed of the origin of the product, which enables direct quality confirmation.

The presented model can be very useful from the potential analysis for the development of agro-food activities of small agricultural households in conjunction with the development of rural tourism.

\section{Analysis of the application of the chain value model of agro-food products in the function of rural tourism in Serbia}

Serbia, for a long period, is undergoing a series of structural changes that are oriented towards the development of market institutions, and it faces some issues. One of the areas in which an optimal solution is to be found is the tendency for rural areas to adapt to the needs of tourism (Trukhachev, 2015). Rural tourism gives priority to rural activities and rural accommodation, and can play a key role in Serbia in terms of diversifying 
the rural economy, thus creating opportunities for job creation, which will generate additional income for rural households, reduce unemployment (especially among women population and young people) and will help maintain and re-settle villages. The significance of this activity is also reflected in the priority of the development of rural tourism that Serbia has given within the National Sustainable Development Strategy for the period 2008 - 2017, and that raising the quality of accommodation and reservations in this area is one of the main leverage models presented in Strategy for tourism development of the Republic of Serbia for the period from 2016 to 2025. The reason for this is

The assessment of the high potential of this activity in the process of sustainable development of the rural area in our country. In the upcoming period, it is possible to improve rural tourism if the road infrastructure is improved in rural areas. International standards and quality assurances in accommodation facilities should be introduced. What is most important is to develop awareness of human resources and the need for their development to understand and take advantage of the opportunities offered by rural tourism in a sustainable way. Serbia has the opportunity to develop rural tourism, although it faces a lack of accommodation capacities and impoverished motivation of the local population to be involved in the development process. Social networks and new internet channels of sales, as one of the means to promote rural tourism, will significantly contribute to this process. (Bićanin, 2018)

Relying on the model (Huller et al., 2017), we believe that cooperation with local farmers, locals and the tourism sector is possible to develop a partnership. Serbian villages have small and diverse agricultural production, which needs to be harmonized to participate in the tourism sector. Also, rural households are fragmented and there is a large number of small holdings that are separate from the tourism sector. The development of a partnership between farmers, rural households and the tourism sector is an important goal for the differentiation of the rural economy.

Figure 2. Marketing channel of agro-food products

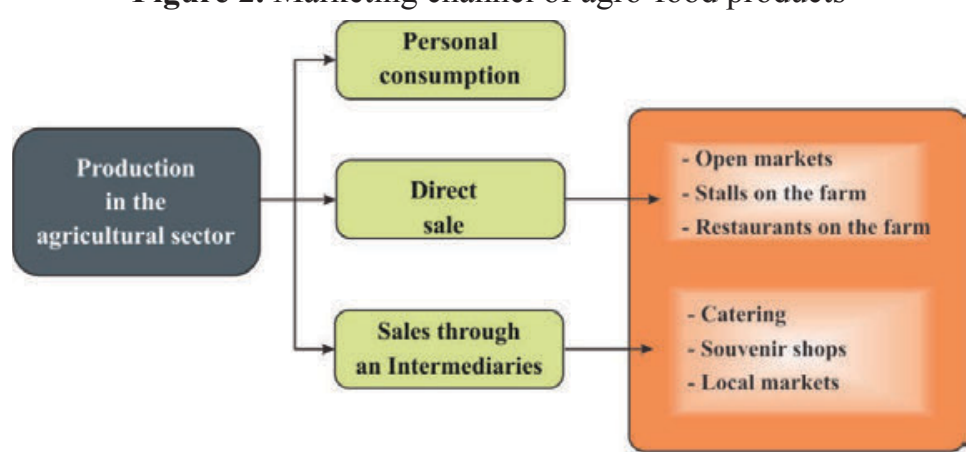

Source: Modified according to Master Plan for Sustainable Rural Tourism of Serbia (2011), p. 104. 
Direct product placement in this model is defined as a process in which agricultural producers directly sell agricultural products to the end user. The process can be carried out through accommodation facilities at the farm, market, stalls at the farm or restaurants on the farm. Indirect placement is defined as the sale of agricultural products to tourism service providers (catering, souvenir shops / national crafts, shops in developed centres for activities) and suppliers of agricultural products (catering, butchers, pilates and self-service).

Direct food suppliers in the marketing channel should be agricultural producers. Rural tourism emphasizes certain jobs that were traditionally performed in households from shadows: cooking, cleaning, handicrafts, etc. Activation and formalization of these activities can result in women having a key role in the development of rural tourism. Commercial skills would be developed by promoting women who produce food and handicrafts. "From marketing, tourism is in the process of maturity characterized by saturation with existing methods of meeting needs", concluded Cvijanović, Mihailović and Vukotić (2016), which opened the space for new models.

The model in question is already beginning to develop in some regions in Serbia. There are more and more agricultural farms whose members are contemplating how to sell food they produce through the development of rural tourism instead to slaughterhouses and dairy. Bojčin Forest, a protected natural good, is an example of public-private partnership. Namely, Bojčin Logs run the municipality, and the ethnic-complex, where the cabin guests are feeding, a private owner. The private owner realized that there is a big benefit for him, which is an agricultural producer if he places his products within the tourist offer. In this way, he sells meat and milk products to tourists at the best possible price. Also, the increased tourist demand has prompted the offer, and other households also offer their products.

\section{Serbian tourism development - a brief analysis of the environment}

The last years of the 20th century and the beginning of the 21 st century have shown that tourism, as a world economy, has achieved primacy over all other branches of economy in all important indicators. Data from the World Tourism Organization (WTO, 2017) for 2002 show that 714.6 million tourist arrivals were recorded in international tourist traffic, which is $3.1 \%$ more than in 2001. During 2001, revenues from international tourism amounted to 463.6 billion USD, or $2.8 \%$ less than in 2000 . According to the WTO forecast, tourist flows will reach 1 billion in 2010 and 1.56 billion by 2020 . (Popescu, 2008). According to the WEF (2017) data in 2016, "travel \& tourism and its enabling system have proven to be significant drivers of economic growth, contributing more than $10 \%$ to global GDP and accounting for 1 in 10 jobs on the planet." Also, travel to rural destinations is in trend. Bearing in mind that the development of this activity represents a general framework for the development of the rural tourism segment, it is important to carry out a brief analysis of the tourism development of tourism in Serbia, and we believe that the relevant period is from 2012. 
Figure 3. Tourists arrivals in Serbia, 2012-2017 (in thousands)

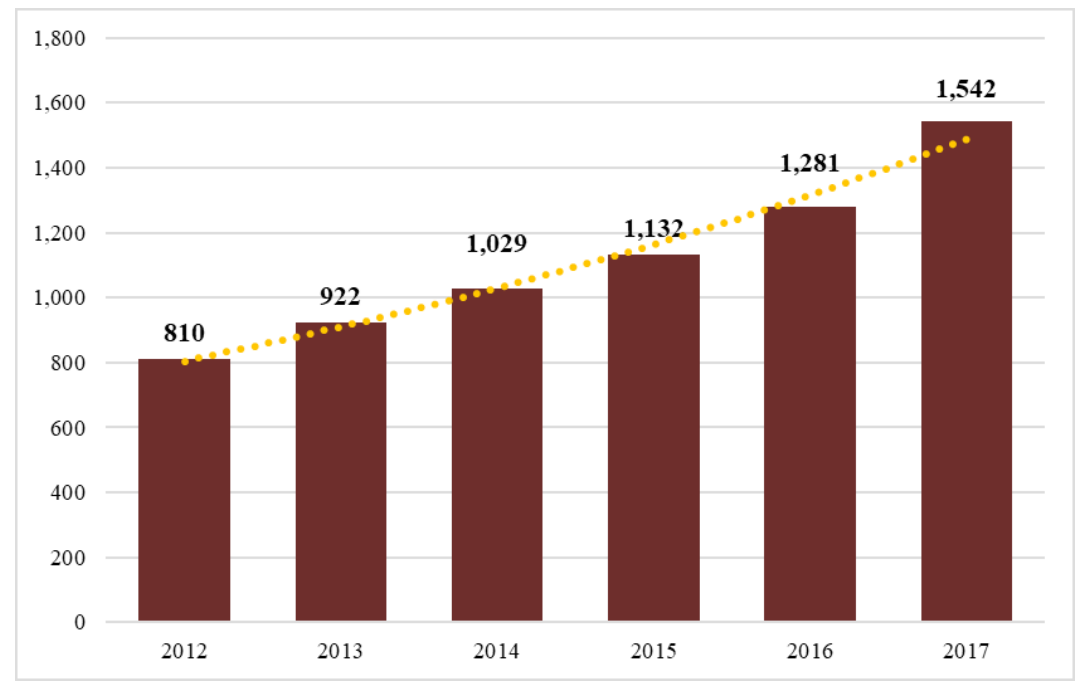

Source: World Tourism Organization (2017), Compendium of Tourism

Statistics dataset [Electronic], UNWTO;

Statistical Office of Serbia database for 2017.

The number of tourists is growing significantly, by the rate of $13.74 \%$ (CAGR), from 810 thousand in 2012 to 1,542 thousand in 2017. According to the same source arrivals in hotels and similar establishment rise from 2,932 thousand in 2011 to 4,131 thousand in 2015 with an increase in 2012 and a decrease in 2013. The expectations are that arrivals will continue to growth. In 2016 foreign arrival in Serbia account for 46.5\% of total arrivals, and show a trend of double-digit growth of $12 \%$ on average annually from 2012. In the same period, domestic arrivals grew by 3.7\%. During this period, total arrivals in hotels and similar establishment rose from 2,932 thousand in 2011 to 4,131 thousand in 2015 with an increase in 2012 and a decrease in 2013. The expectations are that arrivals will continue to growth. Dynamic restructuring of destinations in Serbia toward a modern, experience-oriented product will drive the demand even further.

Total tourism expenditures in Serbia reached 1,461 million in 2016. The travel expenditures make the most of expenditures (79\%), while the passenger transport contributes $21 \%$. In the observed period 2012-2016, total spending of tourists constantly growth, with a minor correction in 2015 , at a rate of $7.8 \%$ (CAGR). The share of personal spending is dominant in 2016 (98\%), while the share of business and professional spending is minor $(2 \%)$. The share of personal spending is dominant in $2016(98 \%)$, while the share of business and professional spending is minor $(2 \%)$. 
Figure 4. Tourist expenditure by the main purpose of the trip, 2012-2016 (USD mn)

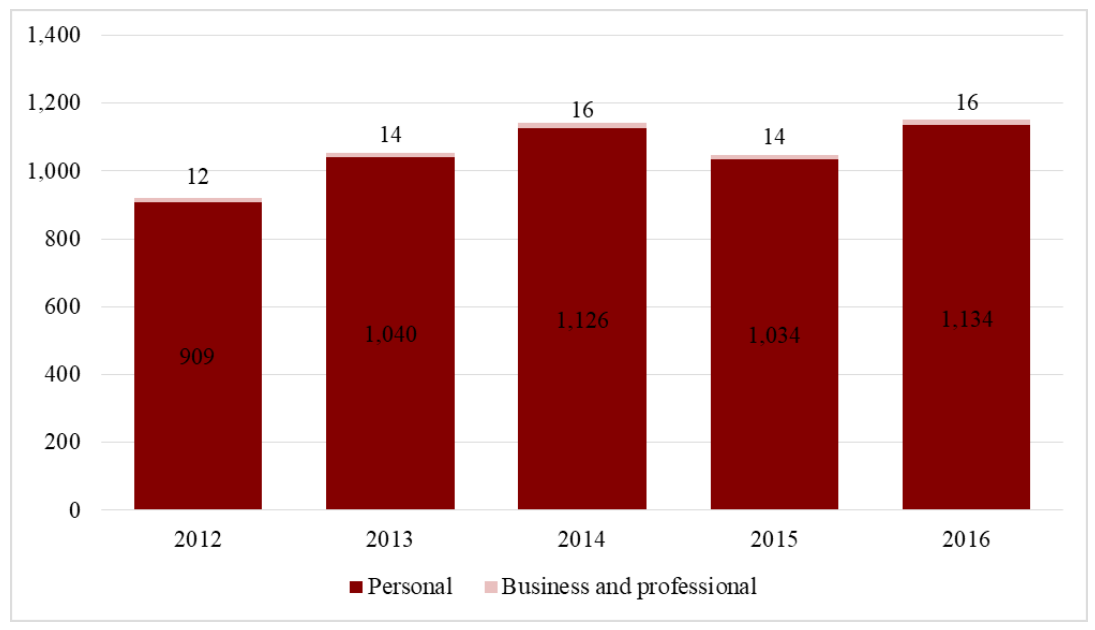

Source: World Tourism Organization (2017), Compendium of Tourism Statistics dataset [Electronic], UNWTO.

Based on the presented data we can conclude that the overall development of tourism in Serbia represents a favourable environment and an incentive for the development of rural tourism. In highly developed countries, about $25 \%$ of tourist flows are directed towards rural destinations, while the worldwide interest is less and accounts for around $10 \%$. In Europe, there are about 200,000 registered households, and it is estimated that about half a million people are directly or indirectly employed in rural tourism with around 2,000,000 beds. Annual tourism spending in rural tourism in Europe is around 26 billion euros, and the number of directly and indirectly employed is estimated at around 500,000. As far as the surrounding countries are concerned, rural tourism is the most developed in Slovenia, and most of our hosts go to study visits to households in this former Yugoslav Republic ("Encouraging rural tourism for sustainable local economic development", 2014). It is also important to have in mind that today problems such as the low standard of living, unemployment and underdeveloped infrastructure, are essential characteristics of both urban and rural areas in the Republic of Serbia (Mandaric, et al., 2017) and that development of tourism can change the circumstances.

Despite the modest statistics for this area, Vujko et al. (2016) state that in Serbia about 1,000 rural households with 8,000 beds are providing tourist services, of which only 300 households report this activity as primary. In the future it is expected that the offer will increase, and considering that there is no record and publicly available data on the number of tourists and overnights for a specific tourist product, the trend can be indirectly analyzed based on the global movement of tourist offer and demand in Serbia, in the last 10 years. 


\section{SWOT Analysis of rural tourism as a marketing channel for food products}

The SWOT analysis method is very effective for evaluating and deciding in various situations in which the system is, regardless of its type and complexity. Identifying the strengths and weaknesses of rural tourism in the context of the marketing channel for food products, as well as the analysis of opportunities and environmental hazards, allows us to see the advantages and disadvantages of the proposed concept.

Table 1. SWOT matrix

Strengths
- Tradition in the production of agro-food products
- High productivity in the production of
Products that are recognizable on the domestic
and international markets (brandy, ajvar, wines,
cheese and cream, fresh fruits and vegetables of
high quality, sweet and jams etc.) and authentic
handicrafts
The tradition and culture of the "Serbian host"
and the imperative that the guest be satisfied
The trend of tourism development in Serbia and
the trend of rural tourism development in Serbia
(an increase of arrivals, an increase in tourist
expenditure) from 2012 to date

\section{Opportunities}

\section{Weaknesses}

- Lack of brands for agricultural products

- Lack of supply chain

- Insufficient knowledge of the local population on tourism activity

- Poor road infrastructure in rural areas

Lack of active and passive vacation content for different target groups

- Small diversification of tourist products

- Insufficient promotion of rural tourism and food products

- Lack of cooperation between agricultural producers

- Lack of standards in food production

\section{Threats}

- Global development of rural tourism in the world and the growth of tourists' interest in these tourist products

- Changing the tourism paradigm

- In 2007, rural tourism was already defined as a product for the future development of tourism in Serbia in the Strategic Plan for Tourism Development of Serbia (2007).

- Defining rural tourism as one of the leverage in the growth model in the Tourism Development Strategy of Serbia in the period from 2016 to 2025.

- Serbia is currently primarily positioned as a natural and cultural destination.

- Poverty Reduction Initiatives

- A relatively simple and inexpensive channel for promoting rural tourism through online services, such as Booking.com or Facebook.

- The possibility of expanding the market through the organization of tourist trips and sales of souvenirs - agricultural products

- Competition - rural tourism offer in countries with similar natural and cultural resources (region of the former SFRY)

- High input costs of agricultural production

- Land fragmentation and spatial dispersion of agricultural producers

- Poor structure of sources of funds and the lack of favourable credit loans, as well as the possible increase in the interest rate

- Turbulent political situation

Source: authors 


\section{Conclusions}

The conclusion based on the SWOT matrix is that the Republic of Serbia has great potential for the development of rural tourism, which is a trend in the countries of the European Union. The interest of tourists for non-standard tourism products is at the forefront of the development of world tourism. One of the highest priorities is the synthesis of agriculture and tourism, which would be the basis for the development of diversification in rural communities. The exceptionally favourable conditions for the development of tourism in the countryside of Serbia are characterized by preserved nature, mild climate, clean air, rich flora and fauna, unpolluted rivers and lakes, a tradition in production.

Insufficient coordination of rural tourism entities has formed an undifferentiated offer. To ensure this, it is essential that tourism service providers cooperate, and also with other entities that plan and direct this development at the macro level. This would have positive effects in the short and long term. Local tourism organizations have improved the development of rural tourism through better marketing at the national level in recent years. Improving the tourist offer in the short term is made up of local and regional events.

Serbia is still in the initial stage of development despite its advantages. Regardless of natural, social and cultural good predispositions, Serbia did not turn its comparative advantage into a competitive one. Activities to improve the tourist offer include: developing and strengthening the supply of rural sector, operational marketing plan, market information system and adjusting manifestations to children. In addition to these, challenges should be overcome by introducing international standards, improving local infrastructure, reducing lapses in the value chain, setting up a rural tourism system for environmental protection that will contribute to raising awareness of environmental protection in the local population and introducing brands for agricultural products. The development and advancement of the rural environment represent a sustainable and stable regional economic development.

\section{Acknowledgements}

This paper represents a part of the research on the projects of the Ministry of Education, Science and Technological Development of the Republic of Serbia, No 179050, entitled: "Strategic and Tactical Measures for Resolving Competitiveness Crisis of the Real Sector in Serbia, No. 179015, entitled: „Challenges and Prospects of Structural Changes in Serbia: Strategic Directions of Economic Development and Harmonization with the EU Requirements " and No. 47009, entitled "European Integrations and Socioeconomic Changes in the Economy of Serbia on the Way to the EU".

\section{Conflict of interests}

The authors declare no conflict of interest. 


\section{References}

1. Akin, H., Shaw, B., Spartz, J. (2015). Promoting Economic Development with Tourism in Rural Communities: Destination Image and Motivation to Return or Recommend. Journal of Extension, 53(2), 1-12.

2. Babović, S., Lović Obradović, S., Pregunova, I. (2016). Depopulation of the village of South Serbia as an obstacle to economic development, available at: http:/www. gi.sanu.ac.rs/site/media/com_form2content/documents/c21/a384/f1107/-\%20 Babovic\%20et\%20al.,\%20srp.pdf (February 15, 2018)

3. Bićanin, J., (2018). Possibilities of Rural Tourism Development in the Area of the Municipality of Trstenik. Economics of Agriculture, 65(1), 355-372, doi: 10.5937/ ekoPolj1801355B.

4. Cvijanović, D., Mihailović, B., Vukotić, S. (2016). Marketing and consulting in the function of tourism development of Serbia, Institute of Agricultural Economics, Belgrade.

5. Fennel, D. (2003). Ecotourism, 2nd ed.; Routledge, Taylor \& Francis Group: London, UK; New York US.

6. Kostić, K. (2011). Definition of the term rural, rural area and rural tourism. University in Novi Sad, available at http://www.dgt.uns.ac.rs/download/seoskitur1. pdf (February 10, 2018)

7. Henderson, J. (2009). Food tourism reviewed, British Food Journal, 111(4), 317 326. doi.org/10.1108/00070700910951470.

8. Hüller, S., Heiny, J., Leonhauser, I-U. (2017). Linking agricultural food production and rural tourism in the Kazbegi district - A qualitative study. Annals of Agrarian Science, 15, 40-48. http://dx.doi.org/10.1016/j.aasci.2017.02.004.

9. Lane, B. (1994). What is rural tourism?, Journal of Sustainable Tourism, Vol. 2, Issue 1-2: 7-21. doi.org/10.1080/09669589409510680.

10. Lederbogen, F., Kirsch, P., Haddad, L., Streit, F., Tost, H., Schuch, P., Wust, S., Pruessner, J.C., Rietschel, M., Deuschle, M., Meyer-Lindenberg, A. (2011). City living and urban upbringing affect neural social stress processing in humans, Nature, Vol. 474, June 2011: 498-474. doi: 10.1038/nature10190.

11. Master Plan for Sustainable Rural Tourism of Republic of Serbia. Belgrade(2011): UN Joint programme 'Sustainable tourism for rural development'. ttps:// futurehospitalityleaders.files.wordpress.com/2012/11/master-plan-odrzivograzvoja-ruralnog-turizma-u-srbiji.pdf (February 20, 2018).

12. Mandarić, M., Milićević, S., Sekulić, D. (2017). Traditional Values in the Function of Promotion of Šumadija and Pomoravlje as Rural Tourism Destinations, Economic of Agriculture, 64(2), 787-804.

13. Milošević, S., Milovanović, J. (2012). Sustainable tourism in the function of rural development - small agricultural holdings and rural tourism in Serbia, Faculty of Applied Ecology Futura, University Singidunum, Belgrade. 
14. Muhi, B. (2013). Rural tourism as a component of the integral and sustainable development of villages in Vojvodina, Proceedings of the Serbian Society for Social Sciences, Vol. 142: 129-137. doi: 10.2298/ZMSDN1342135M.

15. Petrović, M., Vujko, A., Gajić, T., Vuković, D., Radovanović, M., Jovanović, J., Vuković, N. (2017). Tourism as an Approach to Sustainable Rural Development in Post-Socialist Countries: A Comparative Study of Serbia and Slovenia, Sustainablity, Vol. 10, No. 54, doi:10.3390/su10010054.

16. Popesku, J. (2008). Sustainable Tourism, annex in the publication Rural Development and Rural Tourism, Agromreža, Belgrade.

17. Radosavac, A., Knežević, D. (2017). Economic Importance of use of Pesticides in Wheat Production, Economic of Agriculture, 64(4), 1323-1334.

18. Report on the project "Encouraging rural tourism for sustainable local economic development", Development business centre Kragujevac, Kragujevac, Embassy of the Kingdom of Norway, 2014. available at: http://www.ruralniturizam.gtokg.org. rs/ (March 7, 2018).

19. Robinson, R., Getz, D. (2014) Profiling potential food tourists: an Australian study, British Food Journal, 116(4), 690-706, doi.org/10.1108/BFJ-02-2012-0030.

20. Ruzic, P., Demonja, D. (2017). Economic Impacts of Rural Tourism in Rural Areas of Istria (Croatia), Transformations in Business \& Economics, Vol. 16, No 3 (42), 31-40.

21. Smith, S.L., Xiao, H. (2008). Culinary tourism supply chains: a preliminary examination, Journal of Travel Research, 46(3), 289-299.

22. Sparks, B., Roberts, L., Deery, M., Davies, J. and Brown, L. (2005). Good Living Tourism: Lifestyle Aspects of Food and Wine Tourism, Cooperative Research Centre for Sustainable Tourism, Gold Coast.

23. Springer-Heinze, A. (2007). ValueLinks manual: The methodology of value chain promotion. Eschborn, Germany: GTZ.

24. TII (2012). The Paradigm Shift in Travel and Tourism - Win or Die, Mini Market Intelligence Brief. Tourism Intelligence International. West Indies.

25. Trukhachev, A. (2015). Methodology for Evaluating the Rural Tourism Potentials: A Tool to Ensure Sustainable Development of Rural Settlements, Sustainability, Vol. 7: 3052-3070. doi:10.3390/su7033052.

26. Vujko, A., Petrović, M., Dragosavac, M., Gajić, T. (2016). Differences and Similarities among Rural Tourism in Slovenia and Serbia-Perception of the Local Tourism Workers, Economic of Agriculture, 63(4)2016, 1459-1469.

27. WEF. (2017). The Travel \& Tourism Competitiveness Report, Paving the way for a more sustainable and inclusive future. Insight Report. Geneva.

28. World Tourism Organization (2017), Compendium of Tourism Statistics dataset [Electronic], UNWTO. https://www.e-unwto.org/doi/abs/10.5555/unwtotfb06880 10020132017201809. (March, 10, 2018). 